\title{
ЈЕЗИЧКО-СЕМАНТИЧКОМ АНАЛИЗОМ ДО СТИЛЕМА
}

У раду се на примеру народне лирске песме Јарко Сунще на йуй йолазаше показује могућност примене граматичке и семантичке анализе у циљу идентификовања стилема - елемената на којима се заснивају њене идејне и естетске вредности. Граматичком анализом обухваћени су различити језички нивои с намером да се истакну елементи са стилогеном функцијом. Семантичка анализа спроводи се ради утврђивања семантичког језгра, које чине компоненте значења из домена енциклопедијског знања о Сунцу, његове лексичке семантике и симболичког значења.

Кључне речи: језичко-семантичка анализа књижевноуметничког текста, стилогени, настава српског језика и књижевности

1. Схватање књижевног дела представља заједнички интерес науке о књижевности и наставе српског језика и књижевности. Један од начина да се овај циљ оствари и у методолошком и у методичком смислу јесте примена лингвостилистичког приступа књижевном тексту. Овако би се још један квалитет у настави постигао - конкретна примена знања о српском језику у тумачењу естетских и идејних вредности књижевног дела. Чињеница је да се књижевно дело, уз сву његову сложеност, може потпуније спознати уколико боље познајемо његову језичку организацију.

Лингвостилистика се бави изучавањем поступака којима се постиже интензификација типичних структурних и семантичких својстава језика на свим језичким нивоима, како на логичном тако и на емоционалном плану уметничког текста (Pranjić, 1985: 51). Према Р. Катичићу, употребом непредвидљивог редоследа елемената у говорном низу и избором садржаја који се најмање очекује истиче се структура и ток унутрашњег збивања у књижевном делу (Katičić, 1986: 115). Стилеми, као основне јединице лингвостилис-

\footnotetext{
Гордана Штасни, gordanastasni@yahoo.com

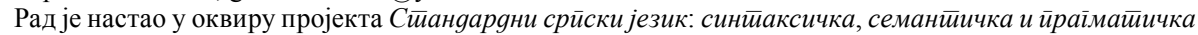
исиираживања (178004), који финансира Министарство просвете, науке и технолошког развоја Републике Србије.
} 
тике, представљају језичке изборе који привлаче читаочеву пажњу. Они се не могу одредити сами по себи, него с обзиром на учесталост стилског избора у датом контексту. То су јединице које носе одређену стилску информацију (Katnić-Bakaršić, 1999: 12).

2. За откривање стилема на различитим језичким нивоима одабрана је народна лирска митолошка песма Јарко Сунце на йуй иолазаше. Н. Килибарда у предговору Срисским нарояним йјесмама из Босне и Хериеїовине (I-III) наводи да је ову песму „Богољуб Петрановић, српски учитељ у турској Босни, ставио намјерно на прво мјесто у књизи" вероватно стога што су се „историјске димензије Босне, вишевјековно ропство посебно, дотакле ових пјесама с прастарим мотивима" (Килибарда, 1989). Иако данас ова песма није део школског програма, узимамо је за пример због њених изузетних вредности, а примењен методолошки приступ може послужити као модел у тумачењу песама сродне тематике. ${ }^{2}$

Митолошке песме припадају древном слоју народне књижевности. То су првенствено песме о женидби Сунца и Месеца; о Сунчевој сестри; о дивовима, змајевима, аждајама, вилама; о подземном свету мртвих (RKT, 1986: 441). Према 3. Карановић, ове песме чувају слојеве прастарих веровања „казујући о томе како је некада могао бити стваран свет из загонетних дубина хаоса, из којег су однекуд израњали Сунце, Месец и звезде, да га обасјају и загреју" (Карановић, 2010: 14).

Песма Јарко Сунще на йуй иолазаше припада ужем кругу песама о небеским телима чија је заједничка карактеристика персонификација небеских тела (Дјевојка и Сунце, Изјеgен овчар, Особииии орач, Женияба сјајноїа Мјесеиа, Сунчева женияба, Сунце се gјевојком жени). Д. Бандић истиче да се у народној књижевности Срба могу уочити фрагменти једне - назовимо је „космичке” митологије. Значајно место у оквирима те митологије имало је Сунце.

„Као и нека друга небеска тела, оно је било персонификовано [...] Према народном предању, персонификација Сунца није се сводила само на његов изглед. Оно је комуницирало са људима и понашало се попут њих. У неким другим предањима Сунце је приказано како једе, пије, купа се, чак и замара. Осећања су му, такође, слична људским. Понекад је весело, понекад тужно и љуто. Има и родбину. Помиње се, рецимо, Сунчева мајка, брат, сестра, ређе жена и деца" (Бандић, 1991: 76-80).

Ова песма се пре реформисаног школског програма обрађивала у VI разреду основне школе и налази се у оквиру тематске целине Сунчеви gарови под насловом Пушиовање Суниа у читанци Крила йлаве иессме коју је приредила Милка Андрић (2002), Београд: Завод за издавање уџбеника. Према новом програму у V разреду је предвиђена обрада обредних народних календарских песама и митолошке песме Граg іраgила б’јела вила (Вила зиgа їpag), у VI разреду се тумаче породичне и обичајне народне лирске песме, у VII - посленичке и љубавне народне песме, у VIII народна лирска песма - Срйска дјевојка. 
Тако су и у одабраној песми Сунцу приписане људске особине, уз истицање његових емоција - саосећања и жеље да огреје „ону многу сиротињу”.

Б. Крстић у Индексу мотиива нароgних иесама балканских Словена (1984) у оквиру прве тематске целине Митологіија, демонолоїија, иеерсонификаиија најпре наводи мотиве везане за Сунце. Међу њима се не налази мотив „путовање Сунца”, али се наводи њему сродан „Бог буди Сунце и шаље га да греје сироте" (Krstić 1984: 2). ${ }^{3}$

У песми Јарко Сунце на йуй йолазаше коегзистира хришћанско веровање у Бога, који помаже Сунцу на његовом путу да огреје цео свет. Стога их В. Латковић (1982: 176) сматра подврстом религиозних народних песама. У њима су народна претхришћанска, паганска, веровања најбоље очувана. Међутим, током времена, уплетена су хришћанска схватања у некада чисто митолошке песме. Вук Караџић је разделио лирске врсте по намени и садржини у двадесет кругова у Срйским нарояним йјесмама (1841). Издвојене су и песме доста неодређеног назива „онако побожне песме” и песме први пут тако назване „особито митологичке”. „Из самих песама јасно је да и међу „онако побожним”, па и међу хришћанским, има видних многобожачких трагова, да митолошких има и другде у разним лирским круговима, и међу љубавним и свадбеним, које се стапају обједињене једним те истим осећањем (Крњевић, 1987: 11).

У песми Kag се Сунце на йуй ойрављало, ${ }^{4}$ која се може сматрати варијантом песме Јарко Сунце на йуй иолазаше, овај аспект је такође уочљив. У песми Kag се Сунце на йуй оирављало изостаје мотив „Божје помоћи Сунцу”, али се јавља мотив „припреме Сунца за путовање” (аналогно припреми јунака за пут, бој и сл.), а парадигму ликова у овој песми чине Сунце, Микула (свети Никола) и свети Петар.

3 Мотив „Бог буди сунце и шаље га да греје сироте” је са потврдама у следећим изворима: Rajković 183; Obradović (S) 132 (Obradović, Milan, Srpske narodne ženske pjesme iz Slavonije, 1890-1891, str. 505 - E. zb. 25/2, str. 175 - E. zb. 44, str. 387 - E. zb. 45); M. H. V, 2 (Hrvatske narodne pjesme, Zagreb, Matica hrvatska, knj. V, 1909); Kuhač V 1941 (Кухач, Фрањо, Јужно-словјенске народне йойиевке, knj. I-V, Zagreb, 1878-1941) (Kostić 1984: 2).

4 Недић, Владан (1972). Анйолоїија нарояних лирских иессама. Београд: Српска књижевна задруга. 
Јарко Сунце на йуй йолазаше, за њим мила мајка йристиајаме: Јарко Сунце, куg ћеш на конаке? Ко ће иесби вечерииу gатии? Ко ће текби ложнииу сиерайи? Ко ће иебе рано ирробудити gа оіријеш земљу и іраgове, а и ону мноіу сиройиюу, іолу, босу и неойасану?

Не брини се, мила моја мајко!

У бої ћу бийи на конаку, божја майи вечерииу gатии,

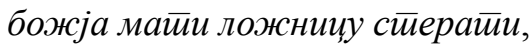
божја матии рано ирробудити и gа оіријем земљу и ірраgове, а и ону мноіу сиройиюу, іолу, босу и неойасану.

\section{0}

Kag се Сунце на йуй ойрављало, Микула му коња осеgлао, свеии Пейар за узде яржао.

Мајка своме Суниу іоворила:

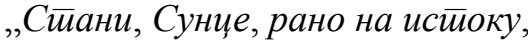
иерр оіријај и стиаро и млаgо, и сироие, мале и нејаке, којено су остиале иррез мајке!"

3. Анализу народне песме Јарко Сунще на йуй йолазаще започињемо од елемента који се у структури песме намеће као доминантан. Наиме, песма је заснована на дијалошкој форми, чија је функција вишеструка. ${ }^{5}$ У првом реду дијалогом који воде Сунце и његова мајка се постиже персонификација ликова. Тоналитет разговора емотивно је обојен бригом мајке за сина који креће на пут. Овим поступком опонаша се патријархални модел и реална ситуација заснована на вези мајка - син. Но, забринутост Сунчеве мајке прераста лично и поприма колективно обележје. То је уједно и компонента песме која је везује за „земаљска“ дешавања. Међутим, у песми је остварена симбиоза људског и космичког принципа што је основна поетска карактеристика народних митолошких песама. Стога је у основи персонификације митолошка представа о Сунцу у свести припадника архаичних култура. Његовим „оживљавањем” човек покушава да приближи оно што му је далеко, тајанствено, необјашњиво, а свакодневно присутно.

Посредством дијалошке форме песма поприма наративни тон, који је управо захваљујући дијалогу чест у народним лирским песмама.

На формалном плану дијалог се реализује управним говором, који се сматра синтаксички „уникатном” формом. У њему се, како то наводи М. Ковачевић, одређене синтаксичке, семантичке и прагматичке категорије примарно, а неке и једино изражавају, као на пример, употреба вокатива,

У прозном и драмском делу дијалог је најчешће у функцији језичке и психолошке карактеризације ликова, доприноси динамичности радње и др. У поезији, међутим, има наглашенију стилску функцију, и то у зависности од учесника у дијалогу. 
императива, узвика, узвичних, упитних, и упитно-узвичних исказа и сл. (Ковачевић, 2011: 30). Такође, управни говор има статус језички маркиране категорије у односу на неуправни говор.

3.1. Стихови којима започиње песма Јарко Сунц̧е на йyй йолазаше имају функцију уводних речница у управни говор и исказани су независним саставним реченицама. На семантичком плану оне описују ситуацију и уводе ликове.

\section{Јарко Сунце на йуй йолазаше,}

за юим мила мајка ирисйајаше:

Употребом имперфекта (йолазаше, йристиајаше), глаголским обликом карактеристичним за приповедање, означавају се радња и стање које су постојале у прошлости у тренутку када их је перципирао наратор или јунак радње. Имперфекат „исказује прошле радње које су или доживљене или их онај ко говори таквима представља" (Танасић, 2005a: 430). То је, према запажању М. Ивић, феномен „ретроспективно дочаране садашњости” (Ивић, 1958: 144). Применом имперфекта се, такође, постиже наративни тон у лирском тексту, што се може сматрати његовим стилским обележјем.

Уколико бисмо уместо имперфеката употребили приповедачки презент, ${ }^{6}$ и даље се задржава компонента доживљености, која потиче од аспектуалности глагола. С. Танасић наглашава да управо категорија доживљености зближује ова два облика. „Они се могу, захваљујући томе, замењивати у реченицама подесним за такву информацију” (Танасић, 2005а: 433). Презент се у приповедању обично јавља од несвршених глагола, и то у низу, сукцесивно као имперфекат. Тада се читалац/слушалац уводи као посматрач у ситуацију о којој се саопштава; њему се сугерише да се обрео у својеврсној садашњости (Танасић, 2005б: 149).

\section{Имперфекат}

Јарко Сунце на йуй иолазаше, за њим мила мајка ирисйајаше:
*Презент

Јарко Сунце на йуй йолази, за юим мила мајка йристиаје:

У наведеним стиховима на плану лексичке семантике издвајамо глагол $\bar{u} р и с \bar{u} а ј а \bar{u} и$, који у контексту стиха остварује секундарно значење 'стално

\footnotetext{
„Заменом овог облика презентом стиче се утисак да се даје слика нечега што се врши или збива, односно што јест у време говора, а не да се вршило, збивало или било у једном одређеном времену у прошлости. Контекст и говорна ситуација, међутим, јасно откривају да и презент у њима, као и имперфекат, означава ово друго, а не оно прво, да су ова два облика ту семантичко-синтаксичке опозиције" (Стевановић, 1972: 90-91).
} 
ићи уз некога'. ${ }^{7}$ На симболичком плану овим се глаголом истиче стална и велика блискост између Сунца и његове мајке (пресликан патријархални модел).

3.2. Након уводних реченица-стихова следи управни говор - стихови које изговара Сунчева мајка у низу упитних реченица. Категоријално значење упитности доводи се у везу с категоријом модалности, а оне подстичу саговорника на вербалну реакцију, на саопштавање одређене информације (директна модалност) (Пипер, 2005: 671).

У складу са типологијом коју наводи П. Пипер, стихови у виду питања јесу ситуативно посебна питања, која се изричу помоћу неке заменичке речи $(\kappa y g[a], \kappa o)$, а према степену информативности - она су отвореног типа. Истовремено она су и иницијална питања јер отварају двочлану микроструктуру „питање - реплика” (Пипер, 2005: 672-679).

С обзиром на ситуацију дочарану у овој песми употреба футура I потпуно је очекивана. ${ }^{8}$ Може се, међутим, покренути питање у вези са стилском обојеношћу футура I и значењем оствареним у стиховима - је ли оно индикативно или релативно? Наиме, Футур I у релативном значењу може означити радње које се понављају. Те радње могу бити и неки поступци који су типични за ту особу. Према Стевановићевом одређењу, то је квалификативни футур, за који као илустрацију наводи футуре свршених глагола (Стевановић, 1979: 673). У нашем случају глаголи су такође перфективног вида са значењем физиолошких радњи (иробуgити и, и посредно изражени: вечерииу gатии презентом. Важано је лексичко значење употребљених глагола јер оно подразумева својство понављања радње у будућности. Квалификативном футуру I приписује се и прошла и садашња и будућа временска вредност. С. Танасић мисли „да у овом случају, као и у случају коришћења футура I у пословицама, треба ипак говорити о посебном фокусирању чињенице да ће се, с обзиром на то да постоји као перманентно својство, то што је речено испољавати на плану будућности" (Танасић 2005a: 436-437).

У контексту стихова остварено је, дакле, релативно значење футура I, a стилска функција појачана је понављањем реченичне структуре (са приближно истим распоредом синтаксичких конституената) и употпуњена римом. Реч је о граматичком паралелизму као конструктивном принципу, који је окосница многих типова поезије, а нарочито народне. ${ }^{9}$ Посебну стилску и естетску вредност има анафора.

\footnotetext{
Значење је наведено према РМС.

У овом типу питања могуће је употребити само аналитичку форму футура I (ко ће иееби вечерици gāuu).

9 О овом феномену је писао Роман Јакобсон анализирајући руске биљине у делу Линївистиика $и$ йоейика (1966). Београд: Нолит.
} 


\section{Јарко Сунце, куд ћеш на конаке? Ко ће йеби вечерииу gатии?

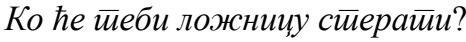 \\ Ко ће йебе рано иробудийи?}

Први стих у управном говору природно започиње обраћањем саговорнику употребом вокатива, за којим следи питње са упитном заменицом (кyg), глаголом $x \bar{u} е \bar{u} и$ у презенту и предлошко-падежном конструкцијом на + акузатив (на конаке), која се може сматрати значењским еквивалентом истоврсног склопа $н a+c \bar{u} а в а њ е$, као номинализованом структуром у служби предиката (ћеш коначийи [на конаке]: ћеш сйавайи [на сйавање]). Прва три стиха-питања независне су синтаксичке конструкције, док четврти стих функционише као главна реченица повезана са зависном намерном реченицом карактеристичним везником $g a$ са предикатом у презенту, која исказује оно што још увек није реализовано, него је сврха ситуације исказане главном реченицом.

„Зависна реченица са ga најфреквентнија је у служби допуне глаголу који функционише као предикат неке друге реченице. У таквом случају синтаксичко својство мобилности односно немобилности бива у првом реду условљено значењем глагола коме реченица са ga служи као допуна. Посебну семантичку класу представљали би глаголи означени као фазни, који представљају фазе у реализацији онога о чему реферише дата синтаксичко-семантичка допуна" (Ивић, 1970: 43-44).

$$
\begin{aligned}
& \text { Ко ће теебе рано ирробудийи, } \\
& \text { gа оїријеш земљу и іраяове, } \\
& \text { а и ону мной сиройиюу, } \\
& \text { іолу, босу и неойасану? }
\end{aligned}
$$

Стихови се богате објектима исказаним беспредлошким акузативом (глагол оїрејайи тражи објекатску допуну). Стилски ефекат у овим стиховима заснован је на набрајању, при чему се издвајају одређене семантичке целине, где је улога везника веома важна: у стварању лексичког споја (земљу $\boldsymbol{u}$ ipagoвe), у функцији укључивања и посебног наглашавања објекта (a $\boldsymbol{u}$ ону мноїу сиройиюу), у издвајању и набрајању конгруентних атрибута у завршном стиху (іолу, босу и неойасану).

На лексичком плану издвајамо спој речи са архаичним тоналитетом

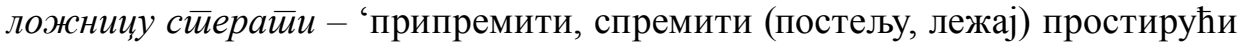
постељину'.

На постављена питања у форми управног говора директно се надовезују одговори. У уводној реченици императив остварује значење савета, подстицаја упућеног саговорнику. Поновљена идентификација реализована је во- 
кативом (мила моја мајко). Узвичном интонацијом појачано је модално значење исказано императивом.

\section{Не брини се, мила моја мајко!}

У одговорима који се нижу доследна је употреба футура I. Анафором и граматичким паралелизмом, те оствареном римом, постижу се стилски и естетски ефекти као у претходним стиховима у управном говору Сунчеве мајке.

У боїа ћу бииии на конаку, божја майи вечерииу gайи,

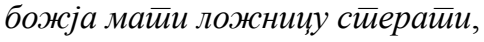

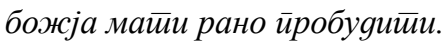

Управни говор Сунца завршава се још једним понављањем намерне зависне реченице, којим се заокружује композиција песме и истиче њена идејна и симболичка димензија.

\section{gа оіријем земљу и іраяове, а и ону мноіу сиротииюу, іолу, босу и неойасану.}

Познато је да се принцип граматичности језичког израза у песничком језику претвара се у принцип хармоничности. „Овакво хармонизирање језичког израза на нивоу граматичке структуре обично потцртава емоционалну обојеност или нијансираност семантичких значења, тако да постајемо свјеснији скривене симболике израза" (Lešić 1982: 295).

4. Како је сагледавање речи као основне језичке јединице недовољно из само једног угла, тако је и групе речи потребно посматрати и описивати са различитих аспеката и интегративно. Зато се у раду примењује и анализа лексичких спојева који могу имати различит статус са синтагматског становишта. Стилски ефекти у песми Јарко Сунще на йуй йолазаше постигнути су посредством структуре одређеног лексичког споја, фреквенцијом његовог појављивања и функцијом у реченици. ${ }^{10}$

Прва именичка синтагма типа Adj + N ( јарко Сунце) употребљена је два пута у песми. Са становишта синтаксе овај је лексички спој употребљен у номинативу у функцији субјекта (Јарко Сунце на пут полазаше) и у упитно интонираној реченици у вокативу у одређеној комуникативној функцији (Јарко Сунце, куд ћеш на конаке?).

10 Фреквентност је један од важних параметара за идентификацију колокационих спојева и њихово разлучивање у односу на синтагматске и идиоматизоване спојеве. 
Са субјекатском синтаксичком функцијом јављају се и синтагме истог структурног типа (мила мајка у стиху „за њим мила мајка пристајаше”;

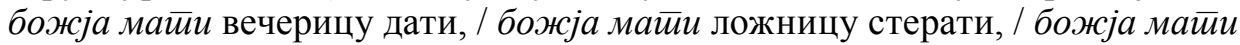
рано пробудити). Употребљена је и трочлана именичка синтагма по моделу $\mathrm{Adj}+$ Pron + N у вокативу (мила моја мајко) у узвично интонираној реченици (Не брини се, мила моја мајко!) са поновљеном комуникативном функцијом обраћања.

Најкомплекснија четворочлана именичка синтагма Pron $+\operatorname{Adj}_{1}+\mathrm{N}+\operatorname{Adj}_{2}$

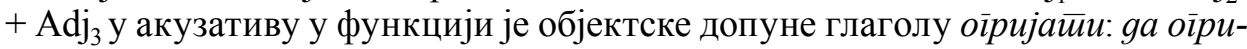
јеш / gа ойријем [...] ону мнойу сиройиюу іолу, босу и неойасану два пута је употребљена у стиховима ове песме.

J. Дражић (2014: 96) констатује да се фокусирањем појединачних иманентних својстава ентитета, формализованих придевско-именичком везом, остварује лексичка веза колокационог типа (јавни наступ). Стога би се и лексички спојеви јарко Сунще и мила мајка могли сматрати колокацијама.

На лексичком плану атрибуте у представљеним синтагмама чине придеви који су у контексту народне поезије са статусом сталних епитета. Њихова је естетска и стилска вредност очувана јер се њима истиче опште својство управног именичког појма: јарко Сунце, мила мајка, или је то лексички спој са посесивном семантичком компонентом израженом заменицом (мила моја

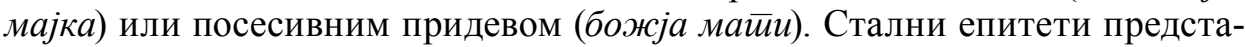
вљају део традиционалног песничког израза у народној поезији, наводи Живковић (Živković, 1968: 84), а њихова је сврха истицање неких општих особина, насупрот оним особинама које служе за истицање индивидуалности (Solar, 1984: 73).

„Као карактеристика која се може, али и не мора дати, као израз говорникове, односно пишчеве, слободе избора, епитет показује извесно расположење онога ко га употребљава, открива његов угао гледања и начин доживљавања света. У усменом песништву тај начин је понајмање личан. Отуда се у народним песмама радо употребљавају стални епитети”, објашњава И. Тартаља (Тартаља, 2008: 98).

Међутим, међу сталним епитетима има много више оних придева који се употребљавају веома често и у обичном говору, тако да је њихова поетичност мање самосталан елеменат стила и много више зависи од контекста у коме се придеви налазе. У фигури поређења синтагма јарко Сунще се веома често јавља као други поредбени члан (појам према којем се врши поређење), на пример: Кад је царе био према цркви, / Сину ирква, као јарко сунще (Зиgање Раванице); У челенци алем камен gраїи, / Који сјаје како јарко сунце (Женияба Максима Црнојевића); На чадору оg злайа јабука, / Она сија, како јарко сунще (Бановић Сирахиња). У народним песмама се често јавља синтагма са сталним епитетима жарко, сјајно, оірејано + Сунце са веома сличним естетским ефектима. 


\begin{tabular}{|c|c|c|}
\hline Народна песма & Стихови & Синтаксичке функције \\
\hline 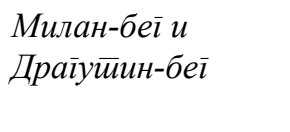 & $\begin{array}{l}\text { Диже цури пули дувак с лица, } \\
\text { Сину лице, кано жарко сунцее, }\end{array}$ & $\begin{array}{l}\text { у поредбеној структури: } \\
\text { девојачко лице ↔ жарко } \\
\text { сунце }\end{array}$ \\
\hline $\begin{array}{l}\text { Цар Дуклијан и } \\
\text { Крсииииељь Јован }\end{array}$ & $\begin{array}{l}\text { Сузан Јован пред Господом } \\
\text { дође, } \\
\text { Сјајно сунцее на небо донесе, }\end{array}$ & $\begin{array}{l}\text { синтагма сјајно сунце } \\
\text { у функцији објекта } \\
\text { исказана беспредлошким } \\
\text { акузативом }\end{array}$ \\
\hline $\begin{array}{l}\text { Како се крсно име } \\
\text { служи }\end{array}$ & $\begin{array}{l}\text { Ал’ беседе господа } \\
\text { ришћанска: } \\
\text { Цар честити, оірејано суниее! }\end{array}$ & \multirow{2}{*}{$\begin{array}{l}\text { Синтагма оіријано } \\
\text { сунцее или у инверзији } \\
\text { сунце оіријано исказана } \\
\text { вокативом у обраћању }\end{array}$} \\
\hline Нахоg Момир & Цар честити, суниее оїрејано! & \\
\hline
\end{tabular}

5. У семантичком опису једне лексеме добро је успоставити релацију између енциклопедијског знања, лексичке семантике и њеног симболичног значења. Тако се применом елемената компоненцијалне анализе, односно декомпоновањем семантичког садржаја наведених значења, могу издвојити семантичке компоненте које представљају значењско језгро одређене лексеме. Овом анализом биће обухваћена лексема Сунце као главни семантички и идејни стожер песме Јарко Сунце на йуй йолазаше.

Једно од важних лексиколошких питања у вези са феноменом значења тиче се разграничавања тзв. језичког од енциклопедијског знања. Према схватању Д. Шипке, „угрубо узев, у језичко знање улази само оно што је довољно да би се одређено значење разграничило од других и одредили његови односи према њима. Енциклопедијско знање, с друге стране, обухвата све оно што одређена друштвена група, или појединац зна о појму који дато значење изражава” (Šipka, 1998: 28). Тако је у енциклопедијским описима присутна алингвистичност јер се приказују сви други атрибути неке датости, који су општег карактера, а не чисто лингвистички. 


\begin{tabular}{|c|c|}
\hline \multicolumn{2}{|r|}{ Лексема Сунце } \\
\hline $\begin{array}{l}\text { Енцикопедијско } \\
\text { знање }\end{array}$ & 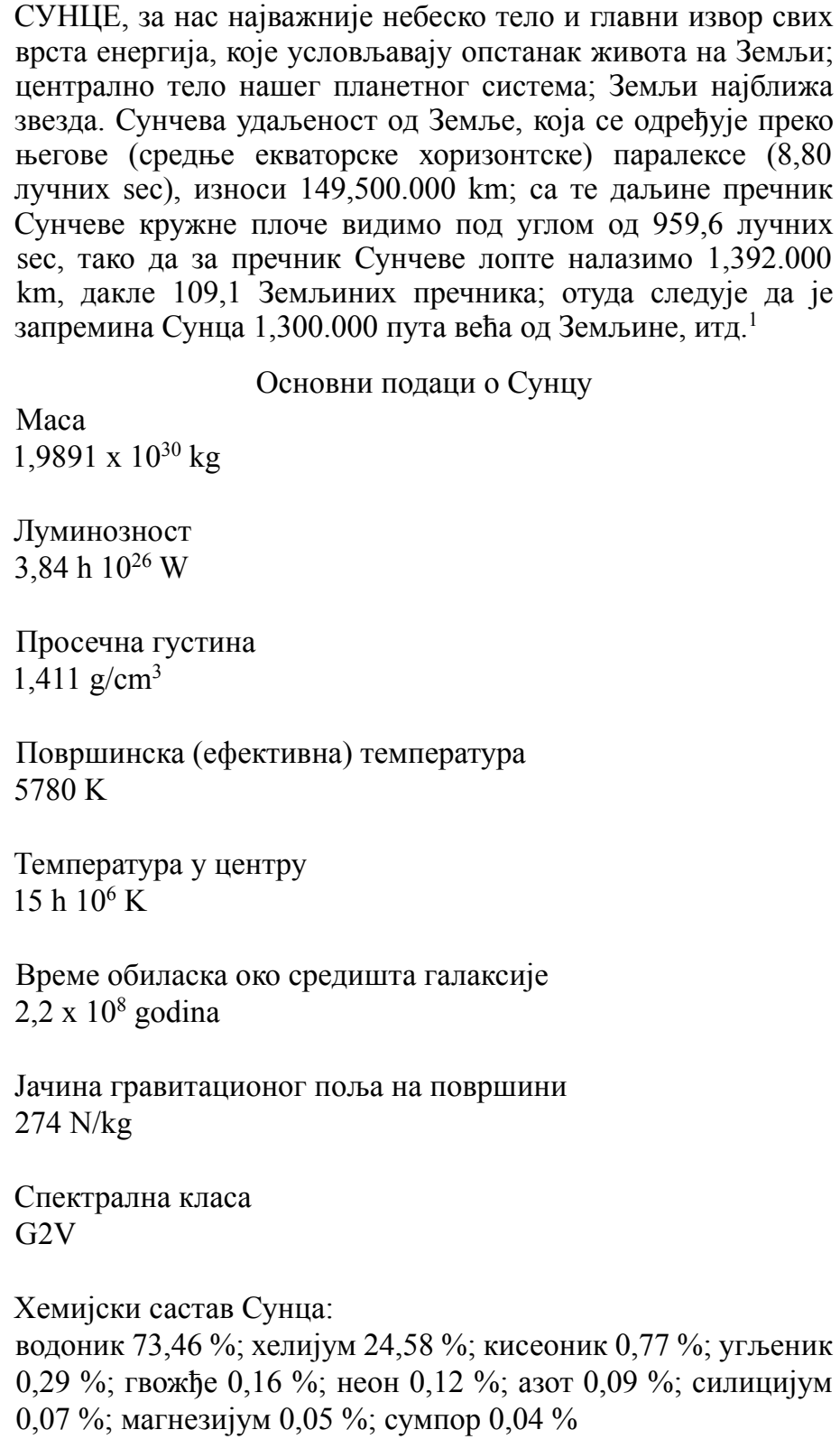 \\
\hline
\end{tabular}

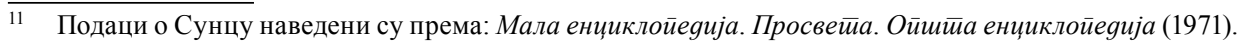
Друго издање. 2. М-Ш. Београд: Просвета. 666. 


\begin{tabular}{|c|c|}
\hline $\begin{array}{l}\text { Лексичка } \\
\text { семантика }\end{array}$ & $\begin{array}{l}\text { 1. астр. а. (Сунце) усијано небеско тело лоптастог облика око } \\
\text { кога се окреће Земља и друге планете. б. мн. централне звезде } \\
\text { других космичких планетних система. } \\
\text { 2. (Сунце) код неких многобожаца биће божанске природе, } \\
\text { бог као творац материјалног и духовног света. } \\
\text { 3. светлост и топлота што их испушта то небеско тело. } \\
\text { 4. фиг. а. оно што се сматра извором нечег, што је од највеће } \\
\text { вредности и значаја за живот. б. (чега) симбол највећих } \\
\text { људских и моралних вредности. в. најдража, најмилија особа } \\
\text { (често у ословљавању). }\end{array}$ \\
\hline $\begin{array}{l}\text { Симболичко } \\
\text { значење }\end{array}$ & $\begin{array}{l}\text { Симболизам сунца је вишеструк и разликује се од културе до } \\
\text { културе. Као општи симбол сунце је извор светлости, топлоте } \\
\text { и живота. Његови зраци представљају небеске или духовне } \\
\text { утицаје што их прима земља. Са једног другог аспекта сунце } \\
\text { је уништитељ, принцип суше - којој је опрека плодоносна } \\
\text { киша (у Кини). Сунце се јавља и као симбол васкрснућа и } \\
\text { бесмртности. Сунце је у средишту неба, као што је срце у } \\
\text { средишту бића. }{ }^{3}\end{array}$ \\
\hline
\end{tabular}

Примарно терминолошко значење лексеме Сунце требало би да кореспондира са енциколопедијским знањем у којем доминира стручни приступ и даје се појмовна вредност лексеме-термина. 


\begin{tabular}{|c|c|c|}
\hline \multicolumn{3}{|c|}{ Декомпонована значења лексеме сунцее } \\
\hline $\begin{array}{l}\text { Енциклопедијско } \\
\text { знање }\end{array}$ & $\begin{array}{l}\text { лексичко } \\
\text { значење }\end{array}$ & $\begin{array}{l}\text { симболично } \\
\text { значење сунца }\end{array}$ \\
\hline \multirow{4}{*}{ 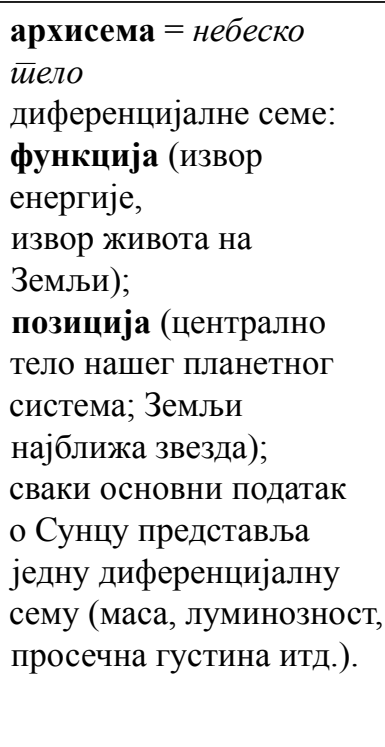 } & $\begin{array}{l}\text { 1.a) архисема }=\text { небеско йело } \\
\text { диференцијалне семе: } \\
\text { a) топлота + облик }+ \\
\text { позиција } \\
\text { б) позиција }\end{array}$ & \multirow{4}{*}{$\begin{array}{l}\text { амбивалентност: } \\
\text { диференцијална } \\
\text { сема: функција } \\
\text { позитиван принцип: } \\
\text { извор светлости, } \\
\text { топлине и живота; } \\
\text { негативан принцип: } \\
\text { уништитељ }\end{array}$} \\
\hline & $\begin{array}{l}\text { 2. архисема }=б о \bar{l}, \bar{u} в о р а и, ~ \\
\text { (метафорично значење) }\end{array}$ & \\
\hline & $\begin{array}{l}\text { 3. архисема = манифестација } \\
\text { (метонимијско значење) } \\
\text { диференцијалне семе: } \\
\text { светлост и топлота }\end{array}$ & \\
\hline & $\begin{array}{l}\text { 4. а) и б) архисема = } \\
\text { вреgносши (духовна) } \\
\text { 4.в. архисема = особа } \\
\text { диференцијална сема: висок } \\
\text { степен блискости } \\
\text { (метафорично значење) }\end{array}$ & \\
\hline
\end{tabular}

Компоненте значења које чине семантичко језгро лексеме Сунце јесу архисема 'небеско тело' и диференцијалне семе високог ранга које садрже информацију о функцији, позицији, топлоти и облику Сунца. Заједничка компонента у енциклопедијском знању и примарном значењу лексеме Сунце (лексичко значење) јесте позиција Сунца у нашем планетарном систему и удаљеност од Земље. Из диференцијалне семе о функцији Сунца (његове манифестације) развила су се секундарна значења (2. и 3) и општа симболична значења Сунца.

6. Закључак. У циљу откривања идејних, стилистичких и естетских вредности књижевноуметничког дела могуће је примењивати елементе лингвостилистичке анализе, која истовремено обезбеђује и теоријскометодолошки и методички приступ књижевном тексту. Модел који је у раду примењен на примеру народне лирске митолошке песме Јарко Сунце на $\bar{u} y \bar{u}$ йолазаще може имати ширу употребу у настави српског језика и књижевности. Са методичког аспекта важно је локализовати песму у жанровски оквир веома богате народне лирске поезије и указати на паралелно постојање митолошких и хришћанских елемената у њој. Таквим приступом се проблематизује прецизно жанровско одређење поетског дела и указује на немогућност строгог класификационог поступка богате и сложене поетске грађе. 
Да би се што успешније примењивала знања из области граматике српског језика у тумчењу уметничког дела и афирмисало природно повезивање знања о језику и знања у домену теорије књижевности, показано је како се граматичком и семантичком анализом могу откривати стилогени елементи у песми. У складу са савременим методичким захтевима у анализи књижевног дела полази се од доминантног структурног елемента.

Анализа песме Јарко Сунце на йу $\bar{u}$ йолазаше открива значајну функцију дијалошке форме која је носећи елемент у структури песме и чијом се употребом реализује кључно стилско и жанровско обележје митолошких песама о небеским телима - персонификација Сунца.

Поред тога, употребом глаголских облика за исказивање времена - имперфекта, футура I, презента и глаголског начина - императива, остварени су, такође, стилски ефекти, што нам открива њихова синтаксичка и семантичка функција. Идентификацијом остварених значења глаголских облика употребљеним у стиховима проблематизује се питање када и како одређена граматичка форма постаје стилоген и у којој је мери његова стилска вредност условљена контекстом. Наиме, стилска вредност граматичке форме - у овом случају наведених глаголских облика, произилази из оствареног значења које је функционално условљено, као и посредством технике понављања (футур I) и њиховом комбинацијом са другим глаголским облицима (имперфекат - футур I - императив - футур I - презент).

Поред сагледавања функције независне саставне и зависне намерне реченице на семантичком и идејном плану песме, анализом су посебно обухваћене синтагматске структуре. Њихова стилска функција тумачи се на основу фреквенције појављивања и функције у реченици, али и лексичког састава, при чему употребљени атрибути са стилистичког аспекта имају статус сталних епитета.

Применом елемената компоненцијалне анализе показано је како се формира сементичко језгро лексеме Сунще, која је кључна реч у песми Јарко Сунце на йуй йолазаме. Оваква врста тумачења лексичких јединица у настави српског језика и књижевности има посебну сврху јер доприноси свеобухватном сагледавању одређене језичке јединице.

Анализе језичкосемантичког типа омогућавају да се у настави функционално повезују сва три предметна подручја - српски језик, књижевност и култура изражавања, да се продуктивно примењују знања из области граматике српског језика и тако оствари један од фундаменталних циљева ове наставе - обухватније сазнавање књижевног дела у наставном процесу. 
Gordana Štasni

\section{LANGUAGE-SEMANTIC ANALYSIS TO STYLEMES}

\section{SUMMARY}

The paper discusses the possibility of applying grammatical and semantic analysis in order to identify stylemes, elements on which ideological and aesthetic values are to be based, by using the example of a lyrical folk poem Јарко Сунце на иууй иолазаше. Different linguistic levels are covered by grammatical analysis in order to highlight elements from stylogenetic functions. Semantic analysis is carried out with the aim to identify the semantic core - meaning components belonging to the encyclopedic knowledge about the sun, its lexical semantics and symbolic meaning.

Key words: language-semantic analysis of literary artistic texts, stylogenetics, teaching Serbian language and literature

\section{ЛИТЕРАТУРА}

Бандић, Д. (1991). Нарояна релиїија Срба у 100 йојмова. Београд: Нолит.

Дражић, Ј. (2014). Лексичке и ірамайичке колокачије у срйском језику. Нови Сад: Филозофски факултет.

Ивић, М. (1958). Систем личних глаголских облика за обележевање времена у српскохрватском језику. Годишњак Филозофской факулиетеи у Новом Саgу, III, 139-149.

Ивић, Милка (1970). Употреба глаголских времена у зависној реченици: презент у реченици с везником gа, Зборник Майице срӣске за филолоїију и линївстиику. XIII/1. 43-54.

Карановић, 3. (прир.) (2010). Анӣолойија срӣске лирске усмене иоозије. Београд: Завод за уџбенике.

Килибарда, Н. (1989). Богољуб Петрановић као сакупљач народних пјесама. Предговор књизи Срйске нароgне ӥјесме из Босне и Хериейовине, I-III, сакупио Богољуб Петрановић, Сарајево: Свјетлост. Преузето са http://www.rastko.rs/rastko-bl/umetnost/ knjizevnost/bpetranovic/nkilibarda-bpetranovic.html

Ковачевић, М. (2011). О типовима говора у Причањима Вука Дојчевића Стефана Митрова Љубише, Годишњак за срйски језик и књижевности. XXIV/10, 27-37.

Крњевић, Х. (прир.) (1987). Различне женске йјесме. Руковейи нарояне лирике. Београд: Београдски издавачко-графички завод.

Латковић, В. (1982). Нарояна књижевносй. Београд: Научна књига.

Пипер, П. (2005). Og саgржаја ка облицима ирросиее реченице. У: Пипер, П., Антонић, И., Ружић, В., Поповић, Љ., \&Тошовић, Б. Синйакса савременоїа срӣскої језика. Простиа реченища. (ред. Ивић, М.). Београд - Нови Сад: Институт за српски језик САНУ - Београдска књига - Матица српска.

РМС: Речник срӣскохрвайскойа књижевної језика (1967-1976). Нови Сад - Загреб: Матица српска - Матица хрватска. 
Стевановић, М. (1972). Глаголски облици као међусобне синтаксичке опозиције, Јужнословенски филолої. XXIX/1-2, 81-103.

Стевановић, М. (1979). Савремени сриискохрвайски језик (Грамайички систиеми и кьижевнојезичка норма), II - Синйакса. (3. изд.). Београд: Научна књига.

Танасић, С. (2005а). Синйакса іллаіола. У: Пипер, П., Антонић, И., Ружић, В., Поповић, Љ., \&Тошовић, Б. Синйакса савременоїа срйской језика. Просйа реченица. (ред. Ивић, М.). Београд - Нови Сад: Институт за српски језик САНУ - Београдска књига - Матица српска.

Танасић, С. (2005б). О перфекту и плусквамперфекту имперфективних глагола, Син-

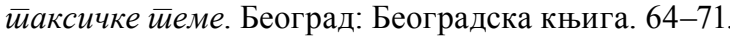

Тартаља, И. (2008). Теорија књижевносии. Београд: Завод за уџбенике.

Katičić, R. (1986). Književnost i jezik. U: Škreb, Zdenko i Ante Stamać. Uvod u književnost. Teorija, metodologija. Zagreb: Globus. 107-133.

Katnić-Bakaršić, M. (1999). Lingvistička stilistika. Preuzeto sa http://rss.archives.ceu.hu/ archive/00001017/01/18.pdf

Krstić, B. (1984). Indeks motiva narodnih pesama balkanskih Slovena. Priredio Ilija Nikolić, Urednik Miroslav Pantić. Beograd: Srpska akademija nauka i umetnosti, Odeljenje jezika i književnosti, knjiga 36.

Lešić, Zdenko (1982). Jezik i književno djelo. Sarajevo: Svjetlost - OOUR Zavod za udžbenike i nastavna sredstva.

Pranjić, K. (1985). Jezik i književno djelo. (3. izd.). Beograd: Nova prosveta.

RKT: Rečnik književnih termina (1986). Glavni i odgovorni urednik Dragiša Živković. Beograd: Nolit.

Solar, M. (1984). Teorija književnosti. Zagreb: Školska knjiga.

Šipka, D. (1998). Osnovi leksikologije i srodnih disciplina. Novi Sad: Matica srpska.

Živković, D. (1968). Teorija književnosti sa teorijom pismenosti. Beograd - Sarajevo: Naučna knjiga - Svjetlost. 